CAM should abide by the rules of evidence-based medicine. My article ${ }^{1}$ is by no means not a 'blanket condemnation' of CAM, it is a critique of the muddled thinking that unfortunately is prevalent in CAM. I am nevertheless thankful to Lakasing and Grover for stimulating further debate that can only, I am sure, be a good thing.

\section{Edzard Ernst,}

Professor, Universities of Exeter and Plymouth, Peninsula Medical School, Complementary Medicine, 25 Victoria Park Road, Exeter, EX2 4NT. E-mail: Edzard.Ernst@pms.ac.uk

\section{REFERENCES}

1. Ernst E. Complementary/alternative medicine: engulfed by postmodernism, anti-science and regressive thinking. Br J Gen Pract 2009; 59(61): 298-301.

2. Ernst E. St John's wort, an anti-depressant? A systematic, criteria-based review. Phytomed 1995; 2(1): 67-71.

3. Ernst E. Complementary and alternative medicine: what the NHS should be funding? Br J Gen Pract 2008; 58(548): 208-209.

DOI: 10.3399/bjgp09X453594

\section{Waste in the NHS}

In January I had the misfortune to sustain a supra-condylar fracture of my femur. Initial pain and subsequent immobility have given me rather too much time to reflect! This reflection was even more poignant as the accident coincided with the escalation of 'co-lateral' casualties in Gaza.

I had almost instant relief from pain by the expert administration of nitrous oxide by efficient paramedics. X-rays were prompt and access to theatre, though a little delayed, was managed without causing any distress on my part.

So what has this to do with waste? My splint was redundant after no more than 5 weeks. It was a splendid affair, not too heavy but reinforced with steel rods and padded with foam, held in place with yards of very wide high quality Velcro ${ }^{\circledR}$ and buckles. Using what I considered to be common sense I took it back to the fracture clinic only to be told that it was unwanted; I could bin it or they would! Home it came, daily glaring dolefully at me from a corner of the hallway.

As a result of this and with the help of Médecins Sans Frontières I tracked down a charity that collects unwanted, but not always unused, medical equipment of any kind; old journals and textbooks but not pharmaceuticals. This is sorted and dispatched mainly to sub-Saharan Africa, but wherever the need is identified, at no cost to the donors or recipients. (The legal requirement is for the charity to provide donors with a transfer of ownership certificate).

In the first 18 months of the establishment of this resource between $£ 70000$ and $£ 100000$ worth of equipment has been distributed, and none of it salvageable by the NHS according to its current guidelines.

If you can encourage local colleagues to join you in this 'recycling' project please contact Human Resource International on 01612250225.

\section{Zoe Kenyon,}

01303267884.

E-mail: zoeshome@tiscali.co.uk

DOI: 10.3399/bjgp09X453602

\section{Depression in younger people}

Surely the headline of your editorial in March presents a false dichotomy. ${ }^{1}$ It led me to reflect on the patients between 16 and 20 years of age who, as a psychiatrist working in a rural area of Scotland, I have seen over the past year. The vast majority of these patients were neither 'clinically depressed' or 'moody'. They did have major emotional problems but these problems were completely understandable in the light of horrendous circumstances that they have been brought up in. One could say that if they didn't feel unhappy there would have been something wrong with them. It is just not true to pretend that there is evidence that medical intervention, whether psychotropic medication or psychological therapy, has been shown to be of major benefit to such folk.

I am proud of what psychiatry can achieve in relieving the chaos of psychosis or the despair of clinical depression, but I think that psychiatry and general practice should reject all efforts made to pretend that they can deal with the understandable sadness of the victims of our horrendous society.

After 30 years as a doctor - in psychiatry and general practice - it is a terrible sadness to see the decline in the quality of life experiences that young people have. I think it is our duty as doctors to point out the facts about the experiences of young people and to endeavour to get society to change its values so that it sees the upbringing of young people as the core function of society. We must not pretend any longer that we can cure the victims of society's failings.

\section{James Finlayson,}

Consultant Psychiatrist, Medical Secretariat, New Craigs Hospital, 6-16 Leachkin Road, Inverness IV3 8NP.

Email: james.finlayson@hs.net

\section{REFERENCE}

1. Iliffe S, Williams G, Fernandez V, Vila M. Treading a fine line: is diagnosing depression in young people just medicalising moodiness? Br J Gen Pract 2009; 59(560): 156-157. 